\title{
ІННОВАЦІЙНА ПЕДАГОГІЧНА ТЕХНОЛОГІЯ ФОРМУВАННЯ ПРАВОПИСНИХ НАВИЧОК У ПЕРШОКЛАСНИКІВ
}

У статті запропоновано інноваційну педагогічну технологію, специфіка якої полягає в тому, що навички грамотного письма формуються без заучування орфографічних і пунктуаційних правил. Триває ознайомлення дітей із «секретами» відтворення усного мовлення на письмі. Розкриття лінгвістичної природи орфографічних явищ з урахуванням графіки української мови зумовило потребу введення узагальненого поняття орфограми на етапі навчання грамоти, а також окремих правил уживання розділових знаків. Поняття орфограми вводиться на прикладі списування слів, що означають власні назви. У поясненні орфограми вчителі керуються визначенням: орфограма - це буква, знак у слові або пропуск між словами, що потребують пояснення.

Ключові слова: технологія, осмислене письмо за зразком, навички грамотного письма, система навчальних вправ.

Oliinyk S. P. Innovative Pedagogical Technology of Formation of Spelling Skills of FirstGraders. The article describes an innovative pedagogical technology, the specificity of which is that the orthography skills are formed without learning spelling and punctuation rules by heart. The acquaintance of children with the "secrets" of the reproduction of oral speech in writing, the disclosure of the linguistic nature of spelling phenomena, taking into account the graphics of the Ukrainian language, necessitated the introduction of a generalized concept of orthograms at the stage of literacy teaching, as well as separate rules for the use of punctuation marks. The concept of orthography is introduced on the example of copying words that mean proper names. While explaining the orthogram, teachers are guided by the definition: an orthogram is a letter, a sign in a word, or a gap between words that have to be explained.

At the beginning of the pre-ABC book period, it is expedient to use propaedeutic exercises throughout the whole period of literacy teaching.

The second group of exercises consists of the ones designed to perform a support role, but which are directly related to the development of literacy skills. A fundamentally new methodical technique in achieving the positive results of introducing meaningful writing by the pattern is the use of a computer program. It provides an opportunity to implement an individual approach, to guarantee high enough cognitive activity of pupils and optimally use the training time. Requirements of the existing ABC books are taken into account in the process of selecting the didactic material for the computer program. The program includes tasks, designed according to the order of the letters studying. Letters, syllables, words, and sentences are used as didactic material.

Consequently, the high efficiency of the developed and tested technology gives grounds to encourage primary school teachers to use this method in the process of first-graders' literacy skills formation.

Key words: technology, meaningful writing by pattern, literacy skills, a system of training exercises.

\section{Ветуп}

Соціальні перетворення в українському суспільстві докорінно змінили пріоритети в галузі освіти. Інноваційна філософія визначила головну стратегію педагогічної діяльності: спрямування навчально-виховного процесу на формування духовного світу особистості, утвердження загальнолюдських цінностей, розкриття й розвиток потенційних можливостей і здібностей учнів. 
Сучасна школа має сприяти розвиткові демократичної культури, формуванню необхідних для проживання в європейському співтоваристві компетентностей, серед яких ключовою є комунікативна, що виявляється в здатності успішно використовувати мову в процесі спілкування, пізнання навколишнього світу, вирішення життєво важливих завдань.

Тому не випадково положення Державного стандарту початкової загальної освіти (19), компетентнісного підходу як методологічної основи формування загальної початкової освіти спрямовані на опанування учнями всіх видів мовленнєвої діяльності, основ культури усного й писемного мовлення, базових умінь і навичок використання мови в різних сферах і ситуаціях спілкування.

Підвалини цих знань створюються саме в початковій школі, завдання якої, окрім інших, - закласти в навчальній підготовці молодших школярів основу грамотного письма, сформувати орфографічну й пунктуаційну зіркість, тобто здатність бачити в тексті особливості графічної форми слова, помічати пунктуаційні знаки в простих випадках, усвідомлювати їх роль у реченні, а також самостійно виправляти допущені помилки, зіставляючи написане зі зразком (Дорошенко, 1995: 64).

Розв'язання цих актуальних проблем можливе лише за умови використання в процесі навчання української мови молодших школярів нових педагогічних технологій.

Упровадження технологій навчання на уроках української мови в початкових класах складає один із перспективних напрямів формування комунікативної компетентності - здатності особистості застосовувати в конкретному спілкуванні знання мови, способи взаємодії з навколишніми й віддаленими людьми та подіями, навички роботи в групі, володіння різними соціальними ролями. Наукові пошуки та досягнення педагогічної науки, соціально-культурний розвиток загальноосвітньої школи, доробок науковців із методики навчання української мови на всіх ступенях освіти (від дошкільного до вищої школи) інформаційно забезпечують розробку новітніх технологій навчання для окремого навчального предмета. Технологічний аспект навчання української мови в початкових класах полягає не в прямому, лінійному перенесенні теоретико-методичних засад сучасного розуміння «технології навчання», а у творчому пошуку шляхів продуктивного навчання української мови молодших школярів.

Центральною в розробці освітніх технологій є проблема правильного визначення та чіткого формулювання цілей навчання. Загальні, розпливчасті цілі не сприяють вибору саме тих методичних засобів, які гарантують досягнення певного результату. Тому, як стверджує О. Я. Савченко (Савченко, 2012), найперша умова побудови технології навчання - конкретизація навчальної мети: зрозуміти, засвоїти, вивчити, зробити, запам'ятати, застосувати за зразком, застосувати в нових умовах тощо. Залежно від мети опрацювання матеріалу визначається і кінцевий результат навчання.

Технологія навчання повинна мати чіткі процесуальні характеристики, тобто настільки зрозуміло, недвозначно описувати, як і що слід робити, щоб 
кожний учитель, застосувавши іiі, гарантовано досягав результату. Шлях від мети навчання до результату - це певним способом організована (за кроками) взаємодія учителя й учнів У цьому відмінність технологічного підходу від звичайних методичних рекомендацій, які допускають внесення змін і не гарантують описаного результату. Технологія також може змінюватися. Скажімо, проконтролювавши й оцінивши проміжний етап навчального процесу, учитель вносить виправлення, зміни в подальшу діяльність. Отже, у технологічній організації навчання обов'язковим є оперативний зворотний зв’язок.

Проте технології теж бувають різні. Зокрема розрізняють педагогічну технологію й технологію навчання, хоча в зарубіжній педагогіці вони синоніми, а їх трактування обмежувалося галуззю навчання і не торкалося процесу виховання. У нас же, хоча й досі не створено єдиного визначення педагогічної технології, загалом воно трактується як широке родове поняття, що включає технологію навчання.

У дослідженнях, проведених Л. Коваль (Коваль, 2009), учителям пропонують сукупність ефективних загальнонавчальних технологій, які мають міжпредметний характер, а саме:

• організація навчальної взаємодії учителя й учнів на основі діалогу та полілогу, де вони виступають суб`єктами навчання. Ця технологія включає прийоми мотиваційної підтримки учнів;

- формування загальнонавчальних умінь і навичок молодших школярів, спрямоване на оволодіння уміннями самоорганізації, способами пізнавальної діяльності, самоконтролю й самооцінювання своєї діяльності з метою оволодіння ключовою компетентністю - уміння вчитися;

- організація диференційованого навчання відповідно до рівня актуальної готовності й зони найближчого розвитку молодших школярів;

- організація навчальної проектної діяльності, орієнтована на самостійну пошуково-творчу працю учнів (індивідуальну, групову) з метою різнобічного пізнання об‘єкта, оволодіння проектними та дослідницькими уміннями, набуття досвіду співпраці й роботи з різними джерелами інформації; організація ігрової діяльності, що має мотиваційну, пізнавальну й виховну значущість і грунтується на залученні молодших школярів до різних видів у процесі засвоєння навчального змісту різних предметів;

- комплексне застосування навчальних технологій з метою організації повного засвоєння учнями навчального матеріалу, що передбачає використання вчителем кількох навчальних технологій для цілеспрямованого опрацювання з учнями тих завдань, які зумовлені вимогами Державного стандарту й навчальних програм.

Із метою ефективного застосування кожної навчальної технології доцільним є алгоритм дій учителя:

- аналіз навчальної ситуації й визначення іiі мети в контексті завдань предмета (теми уроку);

- чітке визначення змісту й структури очікуваного результату засвоєння навчального матеріалу; 
• прогнозування кроків навчальної діяльності учнів для досягнення очікуваної мети;

- передбачення способів зворотного зв'язку з учнями під час застосування технології та способів корекції досягнень;

- передбачення процедури оцінювання навчальних досягнень учнів;

- рефлексія вчителя щодо визначення ефективності обраної технології (15).

\section{Методи та методики дослідження}

Однією з таких технологій, яка сприяє формуванню правописних навичок у першокласників, є осмислене письмо за зразком.

Розроблена технологія спирається на ідеї, оцінені як фундаментальні в сучасній психолого-педагогічній науці. Це - теорія свідомого формування орфографічної навички (Д. М. Богоявленський, 1957; С. Ф. Жуйков, 1965), поетапного формування розумових дій (Л. І. Айдарова, 1978; П. Я. Гальперін, 1985; Н. Ф. Тализіна, 1988), системного вивчення орфографії (П. С. Жедек, Л. І. Тимченко, 1989; В. В. Рєпкін, 1960), взаємозв`язку орфоепічних й орфографічних умінь і навичок (М. С. Вашуленко, 2018; Н. Г. Шкуратяна, 1985), потребу застосовувати опору на мовленнєві кінестезії в навчанні грамотності молодших школярів (Л. К. Назарова, 1978). До уваги було взято рекомендації щодо застосування алгоритму в процесі вироблення в учнів правописної пильності (Н. В. Грона, 2008; С. П. Олійник, 2002; О. Н. Хорошковська, 1992).

Методична концепція осмисленого письма за зразком, покладена в основу експериментального навчання, одержала підтвердження в процесі дослідної перевірки в школах міст Харкова, Полтави, Полтавської області, яка здійснювалася в перших класах чотирирічної початкової школи.

Одним із продуктивних способів формування в першокласників навичок грамотного письма вбачається в перетворенні письма за зразком на етапі навчання грамоти в раціональний засіб оволодіння початковими «секретами» українського правопису.

Специфіка технології полягає в тому, що навички грамотного письма формуються без заучування орфографічних та пунктуаційних правил. Триває ознайомлення дітей із «секретами» відтворення усного мовлення на письмі. Розкриття лінгвістичної природи орфографічних явищ з урахуванням графіки української мови зумовлює потребу введення узагальненого поняття орфограми на етапі навчання грамоти, а також окремих «секретів» уживання розділових знаків.

Можливості першокласників в оволодінні орфографічним матеріалом незначні. Проте цей вік дітей має одну важливу для навчання особливість у них досить розвинена зорова пам'ять. Уведення осмисленого письма за зразком спирається, крім іншого, саме на цю вікову особливість першокласників. До вимог осмисленого списування належить усвідомлене розуміння зразка списування, аналіз його орфографічної форми, у чому допомагає поділ слів на склади, кількаразове їх проговорювання. Практично досягти 
цього можна лише за умови вироблення навички виконання послідовних вимог ознайомлення із зразком, який підлягає списуванню.

\section{Результати та дискусії}

Досягнення мети осмисленого письма за зразком можливе на основі засвоєння алгоритму - усвідомленого поетапного виконання дій, спрямованих на запам'ятання зразка, його орфографічних особливостей для подальшого відтворення. Робота над алгоритмом стає ефективним засобом формування правописної пильності. Елементи алгоритму відомі в педагогічній практиці роботи над орфографією під час вивчення молодшими школярами фонетики і графіки, коли орфографічна грамотність формується з використанням правил. Інновація запропонованої й експериментально перевіреної технології полягає, по-перше, в обгрунтуванні можливості, доцільності й ефективності їі впровадження на етапі навчання грамоти; по-друге, у створенні системи пропедевтичних вправ, які готують першокласників до формування навички осмисленого письма за зразком, без яких упровадження алгоритму не мало б ні психологічного, ні педагогічного обгрунтування. Учням пропонують різні вправи за етапами навчання, за формою виконання, за засобами навчання, за діяльністю вчителя і учня, за характером системного підходу, за формою організації навчання. У запровадженні всіх видів вправ особливого значення надається методичним прийомам, спрямованим на розвиток в учнів самоконтролю.

Принципово новим методичним прийомом у досягненні позитивних результатів запровадження осмисленого письма за зразком є застосування комп'ютерних програм. Вони дають можливість реалізувати індивідуальний підхід, забезпечити досить високу пізнавальну активність учнів й оптимально використати навчальний час.

\section{Висновки}

Порівняння результатів констатувального і формувального експериментів дозволяють зробити висновок про потребу рекомендувати вчителям Нової української школи проводити цілеспрямовану й систематичну роботу з формування раціонального способу списування першокласників. Рекомендована технологія може дати позитивні наслідки за умов продуктивного застосування системи навчальних вправ, які підведуть учнів до усвідомлення того, що від них вимагається.

Це дослідження не висвітлює всього кола проблем, пов’язаних із формуванням у першокласників правописної пильності. Окремого дослідження потребують такі питання, як:

- інтеграційна єдність уроків читання і письма для формування осмисленого письма за зразком;

- подальша розробка та вдосконалення системи пропедевтичних вправ для підготовки першокласників до формування навичок осмисленого письма за зразком з урахуванням вікових особливостей дітей і рівня їхньої підготовки. 


\section{ЛІТЕРАТУРА}

1. Айдарова Л. И. Психологические проблемы обучения младших школьников русскому языку. Москва: Педагогика, 1978. 144 с. 2. Богоявленский Д. Б. Психология усвоения орфографии. Москва: Изд-во АПН РСФСР, 1957. 415 с. 3. Вашуленко М. С. Українська мова і мовлення в початковій школі: Метод. посіб. Київ: Видавничий дім «Освіта», 2018. 400 с. 4. Галыперин П. Я. Методы обучения и умственного развития ребенка. Москва: Изд-во МГУ, 1985. 45 с. 5. Грона Н. В. Формування початкових орфографічних орієнтацій у першокласників під час навчання грамоти. Початкова школа. 2008. № 9. С. 29-33. 6. Дорошенко С. І., Олійник С. П. Робота над орфограмами в першому класі. Початкова школа. 1995. № 12. С. 64-72. 7. Жуйков С. Ф. Формирование орфографических действий (у младших школьников). Москва: Просвещение, 1965. 354 с. 8. Жедек П. С., Тимченко Л. И. Списывание в обучении правописанию. Начальная школа. 1989. № 8. С. 23-28. 9. Коваль Л. В. Професійна підготовка майбутніх учителів початкової школи:технологічна складова. Донецьк: Юго-Восток, 2009. С. 69-99. 10. Лапшина И. Н. Формирование орфографических навыков на начальном этапе обучения русскому правописанию в украинской школе: Дис.... канд. пед. наук. Київ, 1991. 173 с. 11. Львов М. Р. Правописание в начальных классах. Москва: Педагогика, 1990. 159 с. 12. Методика викладання української мови. Навч. посібник для учнів педучилищ і студентів педінститутів /За ред. С. І. Дорошенка. 2-е вид., перероб. і доповнене. Київ: Вища школа, 1992. 398 с. 13. Методика формування правописних навичок у першокласників: навчально-методичний посібник / С. П. Олійник, О. А. Даценко / Полтава: ПДПУ імені В. Г. Короленка, 2002. 73 с. 14. Назарова Л. К. О роли речевых кинестезий в письме. Начальная школа, 1978. № 8. С. 24-27. 15. Освітні технології: Навчально-методичний посібник / О. М. Пєхота, А. З. Любарська та ін.; за заг. ред. О. М. Пєхоти. Київ: А.С.К., 2002. С. 11. 16. Репкин В. В. Формирование орфографического навыка как умственного действия. Вопросы психологии. 1960. № 2. С. 43-47. 17. Савченко О. Я. Дидактика початкової освіти: підручник. Київ: Грамота, 2012. С. 288-293. 18. Талызина Н. Ф. Формирование познавательной деятельности младших школьников: Книга для учителя. Москва: Педагогика, 1988. 175 с. 19. Типові освітні програми для закл. загальної середньої освіти: 1-2 класи. Київ : ТД «ОСВIТАЦЕНТР+», 2018. 240 с. 20. Хорошковська О. Н. Аналіз орфографічного матеріалу 3 української мови. Початкова школа. 1979. № 1. С. 15-20. 21. Шкуратяна Н. Г. Методика вивчення орфографії. Посібник для вчителів. Київ: Освіта, 1985. 133 с.

\section{REFERENCES}

1. Aydarova, L. I. (1978). Psihologicheskie problemyi obucheniya mladshih shkolnikov russkomu yazyiku [Psychological problems of teaching primary school children the Russian language]. Moscow: Pedagogika [in Russian]. 2. Bogoyavlenskiy, D. B. (1957). Psihologiya usvoeniya orfografii [Psychology of spelling mastering]. Moscow: APN RSFSR [in Russian]. 3. Vashulenko, M. S. (2018). Ukrainska mova i movlennia v pochatkovii shkoli [The Ukrainian language and speech at primary school]. Kyiv: Vydavnychyi dim "Osvita" [in Ukrainian]. 4. Galperin, P. Ya. (1985). Metodyi obucheniya i umstvennogo razvitiya rebenka [Methods of teaching and developing a child]. Moscow: Izd-vo MGU [in Russian]. 5. Hrona, N. V. (2008). Formuvannia pochatkovykh orfohrafichnykh oriientatsii u pershoklasnykiv pid chas navchannia hramoty [Formation of first-graders' initial spelling orientations while teaching grammar]. Pochatkova shkola - Primary school, 9. 29-33 [in Ukrainian]. 6. Doroshenko, S. I., \& Oliinyk, S. P. (1995). Robota nad orfohramamy v pershomu klasi [Work on spelling in the first grade]. Pochatkova shkola - Primary school, 12. 64-72 [in Ukrainian]. 7. Zhuykov, S. F. (1965). Formirovanie orfograficheskih deystviy (u mladshih shkolnikov)[ Formation of spelling actions (for primary school children)]. Moscow: Prosveschenie [in Russian]. 8. Zhedek, P. 
S., \& Timchenko, L. I. (1989). Spisyivanie v obuchenii pravopisaniyu [Coping in teaching spelling]. Primary school - Nachalnaya shkola, 8. 23-28 [in Russian]. 9. Koval, L. V. (2009). Profesiina pidhotovka maibutnikh uchyteliv pochatkovoi shkoly:tekhnolohichna skladova [Professional training of future primary school teachers: technological component]. Donetsk: YuhoVostok [in Ukrainian]. 10. Lapshina, I. N. (1991). Formirovanie orfograficheskih navyikov na nachalnom etape obucheniya russkomu pravopisaniyu v ukrainskoy shkole [Formation of spelling skills at the initial stage of teaching Russian spelling in Ukrainian school]. Candidate's thesis. Kyiv [in Russian]. 11. Lvov, M. R. (1990). Pravopisanie v nachalnyih klassah [Spelling in primary school]. Moscow: Pedagogika [in Russian]. 12. Doroshenko, S. I. (Eds.). (1992) Metodyka vykladannia ukrainskoi movy [Methods of teaching Ukrainian] ( $2^{\text {nd }}$ ed., rev.). Kyiv: Vyshcha shkola [in Ukrainian]. 13. Oliinyk, S. P., \& Datsenko, O. A. (2002). Metodyka formuvannia pravopysnykh navychok u pershoklasnykiv [Methods of formation spelling skills of first-graders]. Poltava: PDPU imeni V. H. Korolenka [in Ukrainian]. 14. Nazarova, L. K. (1978). O roli rechevyih kinesteziy v pisme [On the role of speech kinesthesia in writing]. Nachalnaya shkola - Primary school, 8, 24-27 [in Russian]. 15. Piekhota, O. M., Liubarska, A. Z., et al. (2002). Osvitni tekhnolohii [Educational technologies]. Kyiv : A.S.K. [in Ukrainian]. 16. Repkin, V. V. (1960). Formirovanie orfograficheskogo navyika kak umstvennogo deystviya [Formation of spelling skills as mental action]. Voprosyi psihologii - Issues of psychology, 2, $43-47$ [in Russian]. 17. Savchenko, O. Ya. (2012). Dydaktyka pochatkovoi osvity [Didactics of primary school]. Kyiv: Hramota [in Ukrainian]. 18. Talyizina, N. F. Formirovanie poznavatelnoy deyatelnosti mladshih shkolnikov: Kniga dlya uchitelya / Formation of cognitive activity of primary school children: A book for a teacher]. Moscow: Pedagogika [in Russian]. 19. Typovi osvitni prohramy dlia zakladiv zahalnoi serednoi osvity: 1-2 klasy [Typical educational programs for institutions of general secondary education: 1-2 grades]. (2018). Kyiv: TD «OSVITA-TsENTR+» [in Ukrainian]. 20. Khoroshkovska, O. N. (1979). Analiz orfohrafichnoho materialu z ukrainskoi movy [Analyses of Ukrainian spelling]. Pochatkova shkola - Primary school, 1, 15-20 [in Ukrainian]. 21. Shkuratiana, N. H. (1985). Metodyka vyvchennia orfohrafii [Methods of teaching spelling]. Kyiv: Osvita [in Ukrainian].

Олійник Світлана Петрівна - кандидат педагогічних наук, доцент, доцент кафедри філологічних дисциплін і методик їх викладання, Полтавський національний педагогічний університет імені В. Г. Короленка; вул. Остроградського, 2, Полтава, 36000, Україна.

Tel: +38-097-454-07-81

E-mail: sp.oliynik@ukr.net

https://orcid.org/0000-0002-2763-413x

Oliinyk Sitlana Petrivna - PhD in Philology, Associate Professor, Department of Philological Subjects and Methods of Their Teaching, V. H. Korolenko Poltava National Pedagogical University; Ostrohradskoho Str., 2, Poltava, 36000, Ukraine.

Надійшла до редакції 26 лютого 2019 року 